\title{
Vitamin D deficiency in children aged 6 to 12 years: single center's experience in Busan
}

\author{
Young Eun Roh, MD', \\ Bo Ryung Kim, MD', \\ Won Bok Choi, MD', \\ Young Mi Kim, MD, PhD', \\ Min-Jung Cho, MD', \\ Hye-Young Kim, MD, PhD', \\ Kyung Hee Park, MD', \\ Kwang Hoon Kim, MD', \\ Peter Chun, MD', \\ Su Young Kim, MD, PhD², \\ Min Jung Kwak, MD, PhD'
}

${ }^{1}$ Department of Pediatrics, Pusan National University Hospital, Pusan National University School of Medicine, Busan, ${ }^{2}$ Department of Pediatrics, Pusan National University Children's Hospital, Pusan National University School of Medicine, Yangsan, Korea
Purpose: This study investigated the prevalence and risk factors associated with vitamin $\mathrm{D}$ deficiency in children.

Methods: We analyzed the medical records of 330 patients from the age of 6 to 12 , who visited the endocrinology clinic of the Department of Pediatrics at Pusan National University Hospital, from September, 2013 to May, 2014. According to their serum 25-hydroxyvitamin $D(25(\mathrm{OH}) \mathrm{D})$ levels, the patients were grouped into either the deficiency group $(25(\mathrm{OH}) \mathrm{D}<20 \mathrm{ng} / \mathrm{mL})$, or the sufficiency group $(25(\mathrm{OH}) \mathrm{D} \geq 20$ $\mathrm{ng} / \mathrm{mL}$ ). The differences between the 2 groups were compared.

Results: There were 195 patients $(59.1 \%)$ who had vitamin D deficiency. Their mean serum $25(\mathrm{OH}) \mathrm{D}$ level was $14.86 \pm 3.20 \mathrm{ng} / \mathrm{mL}$. The differences in sex, age, and pubertal status between the 2 groups were not statistically significant. Weight standard deviation score (SDS), and body mass index SDS, were significantly higher in the vitamin $D$ deficiency group ( $P=0.002$ for each), compared to the sufficiency group. Compared with Autumn, both Spring (odds ratio [OR], 9.7; 95\% confidence interval [Cl], 4.3-22.0), and Winter (OR, 5.9; $95 \% \mathrm{Cl}, 3.5-10.0)$, were risk factors for vitamin $D$ deficiency. In multiple logistic regression analysis, only seasonal differences have been confirmed to have an effect on vitamin D deficiency.

Conclusion: Vitamin D deficiency in children aged 6 to 12 years is very common. Spring and Winter are the most important risk factors for vitamin D deficiency. We suggest that it is necessary to supplement the guideline for the vitamin $D$ intake according to our situation.

Keywords: Child, Prevalence, Risk factors, Vitamin D deficiency

\section{Introduction}

Vitamin D is an essential vitamin for the health and growth of bones. It is also important for calcium and phosphorus metabolism ${ }^{1}$. There are not many natural food items that contain vitamin $\mathrm{D}$, therefore the amount of time in sunlight is the important source of vitamin $\mathrm{D}^{2)}$. Vitamin D deficiency can result in skeletal diseases, such as rickets and osteomalacia ${ }^{3)}$. In addition, vitamin D receptors exist in the endocrine glands and cardiovascular tissues, and take part in the differentiation of cell, and the production of various cytokines and interleukins, which, taken together, means that they are relevant in metabolic syndromes, diabetes, autoimmune diseases, and cardiovascular diseases ${ }^{4-6)}$. Moreover, respiratory infections, food allergies, and asthma are known to increase with vitamin D deficiency, and there are also reports that menarche starts earlier in vitamin $\mathrm{D}$ deficient girls ${ }^{7-9)}$. The known risk factors associated with vitamin D deficiency are skin pigmentation, older age, lesser sunlight exposure, lower intake of vitamin D rich food or supplements, and higher body mass index (BMI) $)^{5,10,11)}$.

Recently, vitamin D deficiency has become very common in both adults and children, due to a lack of exposure to sunlight ${ }^{12}$. There is still a controversy over the definition of vitamin D status ${ }^{13-15)}$. Therefore, the prevalence of vitamin D deficiency varies widely from country to

Fax: +82-51-240-6205

E-mail: glorymj0123@gmail.com 
country, ranging from 15 to 60 percent $^{10,16)}$. As such, this study aimed to investigate the prevalence, and risk factors of vitamin D deficiency, in children aged 6 to 12 years, to provide a model of treatment.

\section{Materials and methods}

\section{Subjects}

We targeted patients of 6 to 12 years of age, that visited the endocrinology clinic of the Department of Pediatrics at Pusan National University Hospital, from September, 2013 to May, 2014. We selected patients who visited our outpatient clinic for evaluation of growth and pubertal development without any acute illnesses on the day of visit. A total of 330 patients were included in this subject bracket (Table 1). The patients with chronic diseases, such as epilepsy and hypothyroidism, were excluded. Normal weight was defined as being in the 3 rd to 84th percentile, in terms of BMI. Being overweight was defined as being in the 85th to 94th percentile. Obesity was defined as being in the 95th percentile or higher. This was based on the 2007 standard growth chart of Korean children and adolescents. There were 264 girls (80\%) and 66 boys (20\%). Among the patients, $232(70.3 \%)$ had a normal weight, $58(17.6 \%)$ were overweight, and 40 (12.1\%) were obese (Table 1).

Central precocious puberty is the early activation of the hypothalamic-pituitary-gonadal axis, which occurs before 8 years of age in girls, and before 9 years of age in boys ${ }^{17)}$. This study defined idiopathic central precocious puberty as the following: breast budding in girls before the age of 8 , testicular volume equal to or more than $4 \mathrm{~mL}$ or $4 \mathrm{~cm}^{2}$ in boys before the age of 9 , advanced bone age ( 1 year or more compared to the chronological age), and the peak luteinizing hormone level being equal to or higher than $5.0 \mathrm{IU} / \mathrm{L}$ on immunoradiometric

Table 1. Characteristics of the study participants $(n=330)$

\begin{tabular}{lc}
\hline Characteristic & No. (\%) \\
\hline Sex & $66(20.0)$ \\
Male & $264(80.0)$ \\
Female & \\
Body weight & $232(70.3)$ \\
Normal (<85th percentile) & $58(17.6)$ \\
Overweight (85th-95th percentile) & $40(12.1)$ \\
Obese ( $\geq 95$ th percentile) & \\
Season & $50(15.1)$ \\
Spring (Mar-May) & $129(39.1)$ \\
Autumn (Sep-Nov) & $151(45.8)$ \\
Winter (Dec-Feb) & \\
Vitamin D (25[OH]D) & $195(59.1)$ \\
Deficiency (<20 ng/mL) & $135(40.9)$ \\
Sufficiency ( $\geq 20 \mathrm{ng} / \mathrm{mL})$ & \\
Puberty & $288(87.2)$ \\
Normal & $42(12.7)$ \\
Precocious puberty &
\end{tabular}

assay following stimulation with gonadotropin-releasing hormone $^{18)}$. Of the total 330 patients, 42 (12.7\%) were diagnosed with idiopathic central precocious puberty (Table 1).

\section{Study design}

We reviewed the participants' medical records to collect data on their height, weight, pubertal status, bone age, and serum levels of 25-hydroxyvitamin D (25(OH)D), calcium, phosphorus, and alkaline phosphatase (ALP). Pubertal status was evaluated according to the Tanner stages. Bone age was determined using the method defined by Greulich and Pyle. This study was approved by the Institutional Review Board of Pusan National University Hospital, Busan, Korea (approval number: E-2015071).

\section{Laboratory measurements}

The serum 25(OH)D levels were measured using an electrochemiluminescence binding assay (Roche Diagnostics, Indianapolis, IN, USA). The serum calcium, phosphorus, and ALP levels, were also measured. According to their serum $25(\mathrm{OH}) \mathrm{D}$ concentrations, the patients were divided into 2 groups; deficiency $(25(\mathrm{OH}) \mathrm{D}<20 \mathrm{ng} / \mathrm{mL})$, and sufficiency $(25(\mathrm{OH}) \mathrm{D} \geq 20 \mathrm{ng} / \mathrm{mL})$ groups. The definition of vitamin $\mathrm{D}$ status was based on the recommendation of the US Institute of Medicine (IOM) for vitamin $\mathrm{D}^{13)}$.

\section{Statistical analysis}

SAS 9.3 (SAS Institute, Cary, NC, USA) was used for all statistical analysis. Continuous variables were expressed using the mean value and the associated standard deviation. The differences between the vitamin D deficiency group, and the sufficiency group, were compared using a 2 -sample $t$-test. In terms of the categorical values, a chi-square test was used to compare the differences between the 2 groups. Multiple logistic regression analysis was used to analyze the factors that affected vitamin $\mathrm{D}$ deficiency. In all the statistical analyses, $P$-values below 0.05 were considered to be statistically significant.

\section{Results}

A total of 330 patients were included, and their characteristics are presented in Table 1. There were 195 patients (59.1\%) in the vitamin D deficiency group, and 135 patients (40.9\%) in the sufficiency group. The seasons that measurements were taken were Spring, with 50 patients (15.1\%), Autumn, with 129 patients (39.1\%), and Winter, with 151 patients (45.8\%).

Table 2 shows the characteristics of the vitamin D deficiency and sufficiency groups. The mean serum levels of $25(\mathrm{OH}) \mathrm{D}$ were $14.86 \pm 3.20 \mathrm{ng} / \mathrm{mL}$, and $27.01 \pm 5.59 \mathrm{ng} / \mathrm{mL}$, respectively. The differences between the 2 groups in terms of sex, age, and 
pubertal status were not statistically significant. When the patients' weights were separated into normal, overweight, and obese, and the distribution was compared between the 2 groups, the differences were not statistically significant. However, the frequency of overweight and obese patients in the deficiency group was higher, compared to the sufficiency group. Weight standard deviation score (SDS), and BMI SDS, were significantly higher in the vitamin $\mathrm{D}$ deficiency group ( $P=0.002$ for each), compared to the sufficiency group. There were $41(82.0 \%)$ from the deficiency group, and $9(18.0 \%)$ from the sufficiency group, in Spring. In Autumn, there were 42 (32.6\%), and 87 (67.4\%) and there were $112(74.2 \%)$, and 39 (25.8\%) from each group, respectively, in Winter. When compared with Autumn, the patients who were measured in Spring and Winter had higher percentage of vitamin $\mathrm{D}$ deficiency.

The mean serum calcium levels for the vitamin D deficiency group, and the sufficiency group, were $9.67 \pm 0.36 \mathrm{mg} / \mathrm{dL}$ and $9.76 \pm 0.32 \mathrm{mg} / \mathrm{dL}$, respectively (Table 2 ), being significantly lower in the deficiency group $(P=0.018)$. The mean serum phosphorus and ALP levels were not statistically different, between the 2 groups (Table 2). However, there was a tendency that ALP level was higher in the vitamin D deficiency group which had a lower calcium level. When multiple logistic regression was performed, to investigate the factors related to vitamin D deficiency, Spring (OR, 9.7; 95\% CI, 4.3-22.0) and Winter (OR, 5.9; 95\% CI, 3.510.0) were found to be factors significantly affecting vitamin $D$ deficiency, when compared with Autumn (Table 3).

\section{Discussion}

In the present study, we found that vitamin D deficiency was very common among children aged 6 to 12 years. There were

\begin{tabular}{|c|c|c|}
\hline Variable & OR $(95 \% \mathrm{Cl})$ & Adjusted $P$-value ${ }^{a)}$ \\
\hline Sex & & 0.978 \\
\hline Male & 1 (reference) & \\
\hline Female & $1.0(0.5-1.9)$ & \\
\hline Season & & $<0.001$ \\
\hline Spring (Mar-May) & $9.7(4.3-22.0)$ & \\
\hline Autumn (Sep-Nov) & 1 (reference) & \\
\hline Winter (Dec-Feb) & $5.9(3.5-10.0)$ & \\
\hline Body weight & & 0.101 \\
\hline Normal (<85th percentile) & 1 (reference) & \\
\hline Overweight (85th-95th percentile) & $2.1(1.1-4.3)$ & \\
\hline Obese ( $\geq 95$ th percentile) & $1.1(0.5-2.3)$ & \\
\hline Puberty & & 0.886 \\
\hline Normal & 1 (reference) & \\
\hline Precocious puberty & $0.9(0.4-2.1)$ & \\
\hline
\end{tabular}

Table 2. Characteristics of participants according to vitamin D status

\begin{tabular}{|c|c|c|c|c|}
\hline Characteristic & Total & Vitamin D deficiency & Vitamin D sufficiency & $P$-value ${ }^{\text {a) }}$ \\
\hline No. of participants & $330(100)$ & $195(59.1)$ & $135(40.9)$ & \\
\hline Serum 25(OH)D (ng/mL) & $19.83 \pm 7.39$ & $14.86 \pm 3.20$ & $27.01 \pm 5.59$ & \\
\hline Sex & & & & 0.576 \\
\hline Male & $66(20.0)$ & $41(21.0)$ & $25(18.5)$ & \\
\hline Female & $264(80.0)$ & $154(79.0)$ & $110(81.5)$ & \\
\hline Age (yr) & $8.70 \pm 1.24$ & $8.80 \pm 1.22$ & $8.55 \pm 1.26$ & 0.078 \\
\hline Season & & & & $<0.001$ \\
\hline Spring (Mar-May) & $50(15.2)$ & $41(82.0)$ & $9(18.0)$ & \\
\hline Autumn (Sep-Nov) & $129(39.1)$ & $42(32.6)$ & $87(67.4)$ & \\
\hline Winter (Dec-Feb) & $151(45.8)$ & $112(74.2)$ & $39(25.8)$ & \\
\hline Body weight & & & & 0.071 \\
\hline Normal (<85th percentile) & $232(70.3)$ & $128(65.6)$ & $104(77.0)$ & \\
\hline Overweight (85th-95th percentile) & $58(17.6)$ & $41(21.0)$ & $17(12.6)$ & \\
\hline Obese ( $\geq 95$ th percentile) & $40(12.1)$ & $26(13.3)$ & $14(10.4)$ & \\
\hline Puberty & & & & 0.951 \\
\hline Normal & $288(87.3)$ & $170(87.2)$ & $118(87.4)$ & \\
\hline Precocious puberty & $42(12.7)$ & $25(12.8)$ & $17(12.6)$ & \\
\hline Calcium (mg/dL) & $9.71 \pm 0.35$ & $9.67 \pm 0.36$ & $9.76 \pm 0.32$ & 0.018 \\
\hline Phosphorus (mg/dL) & $4.83 \pm 0.52$ & $4.79 \pm 0.52$ & $4.89 \pm 0.51$ & 0.107 \\
\hline $\operatorname{ALP}(I \cup / L)$ & $253.06 \pm 61.54$ & $257.96 \pm 65.89$ & $245.93 \pm 54.06$ & 0.073 \\
\hline Weight SDS & $0.51 \pm 1.01$ & $0.65 \pm 0.98$ & $0.30 \pm 1.03$ & 0.002 \\
\hline Height SDS & $0.46 \pm 1.00$ & $0.55 \pm 1.02$ & $0.34 \pm 0.97$ & 0.061 \\
\hline BMI SDS & $0.41 \pm 1.02$ & $0.55 \pm 0.98$ & $0.19 \pm 1.05$ & 0.002 \\
\hline
\end{tabular}

Values are presented as number (\%) or mean \pm standard deviation.

25(OH)D, 25-hydroxyvitamin D; ALP, alkaline phosphatase; SDS, standard deviation score; BMI, body mass index.

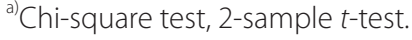


195 patients (59.1\%) with vitamin D deficiency, and their mean serum $25(\mathrm{OH}) \mathrm{D}$ level was $14.86 \pm 3.20 \mathrm{ng} / \mathrm{mL}$. The mean serum $25(\mathrm{OH}) \mathrm{D}$ level of all subjects was $19.83 \pm 7.39 \mathrm{ng} / \mathrm{mL}$ which was also lower than the sufficient vitamin D concentration $(\geq 20$ $\mathrm{ng} / \mathrm{mL}$ ). The prevalence of vitamin D deficiency was found to increase in Spring and Winter, compared with Autumn.

In a previous study on the vitamin D status of Korean children, Lee et al. ${ }^{19)}$ reported the mean serum level of $25(\mathrm{OH})$ $\mathrm{D}$ in 2,880 children and adolescents as $17.42 \pm 8.95 \mathrm{ng} / \mathrm{mL}$. Another study reported that the prevalence of vitamin D deficiency (defined as $25(\mathrm{OH}) \mathrm{D}<20 \mathrm{ng} / \mathrm{mL}$ ) in 1,212 children, aged between 4 and 15 years, was $58.6 \%{ }^{20}$. These results are consistent with the findings of our study.

There is no consensus about the definition of vitamin D status for children and adolescents ${ }^{13-15,21)}$. Globally, a serum $25(\mathrm{OH}) \mathrm{D}$ level below $10 \mathrm{ng} / \mathrm{mL}$ is considered the lowest cutoff for vitamin D status ${ }^{15)}$. However, there are evidences that rickets can occur in infants and young children with a serum $25(\mathrm{OH}) \mathrm{D}$ concentration that is higher than $10 \mathrm{ng} / \mathrm{mL}^{3,22}$. The US IOM suggested that a serum 25(OH)D level above $20 \mathrm{ng} /$ $\mathrm{mL}$ was sufficient for bone health ${ }^{13)}$. After that, the Endocrine Society Task Force published a guideline that defined vitamin D sufficiency as a serum $25(\mathrm{OH}) \mathrm{D}>30 \mathrm{ng} / \mathrm{mL}$, vitamin D insufficiency as a serum $25(\mathrm{OH}) \mathrm{D} 20-30 \mathrm{ng} / \mathrm{mL}$ and vitamin $\mathrm{D}$ deficiency as a serum $25(\mathrm{OH}) \mathrm{D}<20 \mathrm{ng} / \mathrm{mL}^{14)}$. That was because there were increasing evidences that the optimal level of $25(\mathrm{OH}) \mathrm{D}$ might be above $30 \mathrm{ng} / \mathrm{mL}$ in adults ${ }^{23,24)}$. Recently, the Korean Nutrition Society used the definition of the IOM to set the dietary reference intake (DRI) for vitamin D in 2015 $5^{25}$.

It has been reported that the further away from the equator one resides, the shorter the yearly duration of ultraviolet $\mathrm{B}$ irradiation, sufficient for vitamin D synthesis ${ }^{26)}$. In Korea (latitude $33-38^{\circ} \mathrm{N}$ ), sunlight is known to be effective in synthesizing vitamin D from April to October, from 10 in the morning to 3 in the afternoon ${ }^{14)}$. There are reports regarding the seasonal effect on variations in serum 25(OH)D levels according to differences in latitude. In the Northern hemisphere, serum 25(OH)D levels are reported to gradually decrease from Summer to Winter ${ }^{27-30)}$. In the present study, the serum 25(OH)D levels measured in Spring and Winter, were lower than in Autumn, however Summer was not included in our study. According to Foo et al. ${ }^{31}$, the serum $25(\mathrm{OH}) \mathrm{D}$ levels of adolescent girls in Beijing, China (latitude $40^{\circ} \mathrm{N}$ ), were 14.4 $\mathrm{ng} / \mathrm{mL}$ when participating in sports, and $12 \mathrm{ng} / \mathrm{mL}$ when not participating in sports. Another study reported that during Winter, $40 \%$ of the adolescent girls tested, in Beijing, showed vitamin D deficiency. In Mongolia, (latitude $42-50^{\circ} \mathrm{N}$ ), which is adjacent to China, ultraviolet light exposure is reported to be sufficient only in Summer, and the risk of vitamin D deficiency increases in Winter ${ }^{32)}$.

The changes in lifestyle of modern society has caused an increase in indoor activities, decreasing exposure to sunlight among children and adolescents. Lee et al. ${ }^{33)}$ reported that the time spent in the daylight was only $2.6 \mathrm{hr} / \mathrm{wk}$ in winter and 3.9 $\mathrm{hr} / \mathrm{wk}$ in summer in 100 Korean children aged between 5 years and 13 years. Also they showed that vitamin D deficient children spent fewer hours outdoors in the daytime than vitamin $\mathrm{D}$ nondeficient children ${ }^{33}$. We did not measure the time spent in the sunlight, but the decrease in outdoor activities could also be a cause of the high prevalence of vitamin D deficiency in the present study. The Korean Nutrition Society determined the DRI for vitamin D under the assumption that sunlight exposure might be enough to meet vitamin D needs in Korean children ${ }^{25}$. The current DRI for vitamin D in Korean children aged 1-12 years is $200 \mathrm{IU} /$ day which is lower than $600 \mathrm{IU} /$ day of the IOM guideline ${ }^{13)}$. We need more research on Korean children's sunlight exposure.

Obese individuals are known to have a lower level of vitamin $\mathrm{D}$, compared with individuals of a normal weight ${ }^{34)}$. In vitamin D deficiency, key enzymes that act on adipose tissue such as lipoprotein lipase and fatty acid synthase are thought to be inhibited, thereby affecting fat accumulation. Vitamin D3 is stored in subcutaneous fat, and the vitamin D3 synthesized in the skin of obese individuals become more sequestered. Due to this decrease in the bioavailability of vitamin D3, vitamin D deficiency appears more often in obese individuals ${ }^{35}$. The present study shows a significant difference between the vitamin D deficiency and sufficiency groups, in terms of weight SDS and BMI SDS. In spite of this, when multiple logistic regression analysis was used to analyze the factors affecting vitamin D deficiency, weight was not a statistically significant factor.

There have been several studies on the relationship between vitamin D status and sexual maturation. According to Grivas et al. $^{36)}$, menarche started at a younger age at Northern latitudes, where the level of vitamin D synthesis is lower. Villamor et al. ${ }^{37)}$ followed a cohort of 242 healthy girls, from the age of 5 to 12 years, for 30 months, and observed that menarche occurred earlier in those with vitamin D deficiency. They explained that vitamin D deficiency is related to obesity and as such the vitamin $\mathrm{D}$ status would have indirectly affected menarche age. In the present study, there was no significant difference in pubertal status between the vitamin D deficiency and sufficiency groups.

There are a number of limitations to the present study. This is a hospital-based study, and most of the patients live in Busan, and as such this data may not be representative of the whole population of Korea. The levels of parathyroid hormone, which is one of the important factors affecting vitamin D status, were not measured. Of the 4 seasons, Summer was not included.

In conclusion, vitamin D deficiency in children aged 6 to 12 years is very common, and Spring and Winter are the most important risk factors for vitamin D deficiency. Efforts need to be made to improve the vitamin D status, such as increasing outdoor activities for more exposure to sunlight, and taking vitamin D supplements during seasons when vitamin D deficiency is widely prevalent. Furthermore, we suggest that it is necessary to supplement the guideline for vitamin D intake according to our situation. 


\section{Conflict of interest}

No potential conflict of interest relevant to this article was reported.

\section{Acknowledgments}

This work was supported by a clinical research grant from Pusan National University Hospital 2015. We acknowledge assistance with statistical analysis from Pusan National University Hospital Clinical Trial Center Biostatistics Office.

\section{References}

1. Wacker M, Holick MF. Vitamin D - effects on skeletal and extraskeletal health and the need for supplementation. Nutrients 2013;5:111-48.

2. Holick MF. Vitamin D deficiency. N Engl J Med 2007;357: 266-81.

3. Pettifor J, Daniels E, Feldman D. Vitamin D deficiency and nutritional rickets in children. In: Feldman D, Glorieux FH, Pike JW, editors. Vitamin D. San Diego: Academic Press. 1997:663-78.

4. Verstuyf A, Carmeliet G, Bouillon R, Mathieu C. Vitamin D: a pleiotropic hormone. Kidney Int 2010;78:140-5.

5. Harel Z, Flanagan P, Forcier M, Harel D. Low vitamin D status among obese adolescents: prevalence and response to treatment. J Adolesc Health 201 1;48:448-52.

6. Temmerman JC. Vitamin D and cardiovascular disease. J Am Coll Nutr 2011;30:167-70.

7. Searing DA, Leung DY. Vitamin D in atopic dermatitis, asthma and allergic diseases. Immunol Allergy Clin North Am 2010;30:397-409.

8. Eder W, Ege MJ, von Mutius E. The asthma epidemic. N Engl J Med 2006;355:2226-35.

9. Chew A, Harris SS. Does vitamin D affect timing of menarche? Nutr Rev 2013;71:189-93.

10. Absoud M, Cummins C, Lim MJ, Wassmer E, Shaw N. Prevalence and predictors of vitamin D insufficiency in children: a Great Britain population based study. PLoS One 2011;6:e22179.

11. Tolppanen AM, Fraser A, Fraser WD, Lawlor DA. Risk factors for variation in 25-hydroxyvitamin $\mathrm{D}_{3}$ and $\mathrm{D}_{2}$ concentrations and vitamin D deficiency in children. J Clin Endocrinol Metab 2012;97:1202-10.

12. Munns CF, Simm PJ, Rodda CP, Garnett SP, Zacharin MR, Ward LM, et al. Incidence of vitamin D deficiency rickets among Australian children: an Australian Paediatric Surveillance Unit study. Med J Aust 2012;196:466-8.

13. Ross AC, Manson JE, Abrams SA, Aloia JF, Brannon PM, Clinton SK, et al. The 2011 report on dietary reference intakes for calcium and vitamin D from the Institute of Medicine: what clinicians need to know. J Clin Endocrinol Metab 2011;96:53-8.
14. Holick MF, Binkley NC, Bischoff-Ferrari HA, Gordon CM, Hanley DA, Heaney RP, et al. Evaluation, treatment, and prevention of vitamin D deficiency: an Endocrine Society clinical practice guideline. J Clin Endocrinol Metab 2011;96:1911-30.

15. Spiro A, Buttriss JL. Vitamin D: an overview of vitamin D status and intake in Europe. Nutr Bull 2014;39:322-50.

16. Akhtar S. Vitamin D status in South Asian populations: risks and opportunities. Crit Rev Food Sci Nutr 2016;56:1925-40.

17. Carel JC, Léger J. Clinical practice: precocious puberty. N Engl J Med 2008;358:2366-77.

18. Neely EK, Wilson DM, Lee PA, Stene M, Hintz RL. Spontaneous serum gonadotropin concentrations in the evaluation of precocious puberty. J Pediatr 1995;127:47-52.

19. Lee DY, Kwon AR, Ahn JM, Kim YJ, Chae HW, Kim DH, et al. Relationship between serum 25-hydroxyvitamin D concentration and risks of metabolic syndrome in children and adolescents from Korean National Health and Nutrition Examination survey 2008-2010. Ann Pediatr Endocrinol Metab 2015;20:46-52.

20. Chung IH, Kim HJ, Chung S, Yoo EG. Vitamin D deficiency in Korean children: prevalence, risk factors, and the relationship with parathyroid hormone levels. Ann Pediatr Endocrinol Metab 2014;19:86-90.

21. Rovner AJ, O'Brien KO. Hypovitaminosis D among healthy children in the United States: a review of the current evidence. Arch Pediatr Adolesc Med 2008;162:513-9.

22. Arnaud SB, Stickler GB, Haworth JC. Serum 25-hydroxyvitamin D in infantile rickets. Pediatrics 1976;57:221-5.

23. Giovannucci E, Liu Y, Hollis BW, Rimm EB. 25-hydroxyvitamin $D$ and risk of myocardial infarction in men: a prospective study. Arch Intern Med 2008;168:1174-80.

24. Heaney RP, Dowell MS, Hale CA, Bendich A. Calcium absorption varies within the reference range for serum 25-hydroxyvitamin D. J Am Coll Nutr 2003;22:142-6.

25. The Korean Nutrition Society. Dietary reference intakes for Korean 2015 [Internet]. Seoul: The Korean Nutrition Society; c2017 [cited 2016 Apr 13] Available from: http:// www.kns.or.kr/

26. DeLuca HF. Overview of general physiologic features and functions of vitamin D. Am J Clin Nutr 2004;80(6 Suppl):1689S-1696S.

27. Öhlund I, Silfverdal SA, Hernell O, Lind T. Serum 25-hydroxyvitamin D levels in preschool-age children in northern Sweden are inadequate after summer and diminish further during winter. J Pediatr Gastroenterol Nutr 2013;56:551-5.

28. Gordon CM, DePeter KC, Feldman HA, Grace E, Emans SJ. Prevalence of vitamin D deficiency among healthy adolescents. Arch Pediatr Adolesc Med 2004;158:531-7.

29. Guillemant J, Taupin P, Le HT, Taright N, Allemandou A, Pérès $G$, et al. Vitamin D status during puberty in French healthy male adolescents. Osteoporos Int 1999;10:222-5.

30. Weng FL, Shults J, Leonard MB, Stallings VA, Zemel BS. Risk 
factors for low serum 25-hydroxyvitamin D concentrations in otherwise healthy children and adolescents. Am J Clin Nutr 2007;86:150-8.

31. Foo LH, Zhang Q, Zhu K, Ma G, Trube A, Greenfield $\mathrm{H}$, et al. Relationship between vitamin D status, body composition and physical exercise of adolescent girls in Beijing. Osteoporos Int 2009;20:417-25.

32. Fraser DR. Vitamin D-deficiency in Asia. J Steroid Biochem Mol Biol 2004;89-90:491-5.

33. Lee YA, Kim JY, Kang MJ, Chung SJ, Shin CH, Yang SW. Adequate vitamin D status and adiposity contribute to bone health in peripubertal nonobese children. J Bone Miner Metab 2013;31:337-45.
34. Bell NH, Epstein S, Greene A, Shary J, Oexmann MJ, Shaw S. Evidence for alteration of the vitamin D-endocrine system in obese subjects. J Clin Invest 1985;76:370-3.

35. Wortsman J, Matsuoka LY, Chen TC, Lu Z, Holick MF. Decreased bioavailability of vitamin D in obesity. Am J Clin Nutr 2000;72:690-3.

36. Grivas TB, Vasiliadis E, Mouzakis V, Mihas C, Koufopoulos G. Association between adolescent idiopathic scoliosis prevalence and age at menarche in different geographic latitudes. Scoliosis 2006;1:9.

37. Villamor E, Marin C, Mora-Plazas M, Baylin A. Vitamin D deficiency and age at menarche: a prospective study. Am J Clin Nutr 2011;94:1020-5. 